\title{
The Influence of Prophetic Leadership and Job Satisfaction toward Organizational Citizenship Behavior (OCB) on Employees of Prof. Dr. H. Kadirun Yahya Foundation in Medan
}

\section{Sherry Hadiyani * (D), Abdhy Aulia Adnans (D), Ferry Novliadi (D), and Fahmi} Department of Psychology, Faculty of Psychology, Universitas Sumatera Utara, 20155, Medan, North Sumatra Province, Indonesia

* Corresponding Author: sherryhadiyani@usu.ac.id

\section{ARTICLE INFO}

\section{Publication Info:}

Research Article

How to cite:

Hadiyani, S., Adnans, A. A.,

Novliadi, F., E Fahmi, F. (2021).

The Influence of Prophetic

Leadership and Job Satisfaction toward Organizational Citizenship Behavior (OCB) on Employees of

Prof. Dr. H. Kadirun Yahya

Foundation in Medan. Society, 9(1), 94-106.

DOI: 10.33019/society.v9i1.291

Copyright (C) 2021. Owned by Author(s), published by Society

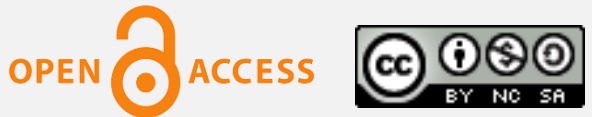

This is an open-access article.

License: Attribution-

NonCommercial-ShareAlike (CC BY-NC-SA)

Received: January 13, 2021;

Accepted: June 8, 2021;

Published: June 11, 2021;

\section{ABSTRACT}

This study aims to determine the influence of prophetic leadership and job satisfaction toward organizational citizenship behavior (OCB) on employees of Prof. Dr. H. Kadirun Yahya Foundation in Medan. The study used a survey model involving 64 employees of Prof. Dr. H. Kadirun Yahya Foundation in Medan. The data were analyzed using multiple linear regression. The results indicated that prophetic leadership and job satisfaction significantly positively influenced organizational citizenship behavior (OCB). The coefficient of the determinant $\left(R^{2}\right)$ of prophetic leadership and job satisfaction showed a value of 0.134, meaning that variation of organizational citizenship behavior is influenced by prophetic leadership and job satisfaction as much as 13.4\%, and other factors influenced the rest.
Keywords: Job Satisfaction; Organizational Citizenship Behavior; Prophetic Leadership

Copyright (C) 2021. Owned by Author(s), published by Society. This is an open-access article under the CC-BY-NC-SA license. 


\section{The Influence of Prophetic Leadership and Job Satisfaction toward Organizational Citizenship}

Behavior (OCB) on Employees of Prof. Dr H. Kadirun Yahya Foundation in Medan

\section{Introduction}

An organization is a complex unit that seeks to maximize human resources for the achievement of its goal. In essence, an organization aims to make a profit and sustain business in the long term. In a globalization era, which is marked by rapid changes in economic conditions, there will be competition in various organizations. Therefore, an organization must have strategic steps toward change and able to increase competitiveness.

Today, organizations need employees who are willing to exert optimal performance for the achievement of organizational goals. Optimal performance needs teamwork. Therefore it requires employees ready to work extra-roles, not only intra-roles (Pio \& Tampi, 2018). Extra role behavior is attempting to benefit the organization, which goes beyond existing role expectations (Organ et al., 2006). This concept is known as organizational citizenship behavior (OCB). OCB is a preferred behavior that is not part of an employee's formal work obligations but supports the effective functioning of the organization. The form of OCB is an extra-role that required a sense of volunteerism (Organ et al., 2006). Lim et al. (2020) stated that Organizational Citizenship Behavior offers enormous benefits to teams and encourages organizational functioning and efficiency.

Prof. Dr. H. Kadirun Yahya Foundation is an organization engaged in education that cannot be separated from the scientific background of the founder, Mr. Prof. Dr. H. Kadirun Yahya, which is Islamic Metaphysics, part of Sufism and Tarekat. By studying the philosophy of spirituality and Islamic Metaphysics in the sections of Sufism, he saw that the power of the Holy Quran is classified as real science; only its dignity and dimensions are much higher and absolute. To raise Islamic Metaphysics to the surface, Mr. Prof. Dr. H. Kadirun Yahya established the Metaphysics Academy Foundation in 1956 in Medan, which has changed its name to Prof. Dr. H. Kadirun Yahya Foundation since 1980. Until now, Prof. Dr. H. Kadirun Yahya Foundation have been evolving into several business units, namely Universitas Pembangunan Panca Budi (Unpab), Perguruan Panca Budi, and other.

This foundation applied Islamic values to its employees and students. This cannot be separated from the role of a leader that employees love. The implementation of Islamic values by the foundation aims to create a positive mental attitude towards students and employees to realize organizational goals effectively. Prof Dr. H. Kadirun Yahya Foundation employees applied seven fundamental values in their activities, which read orally after praying together every day. The seven fundamental values are (1) Maintaining the purity of faith (tauhid) and carrying out shari'at (prayer, dhikr), (2) Being grateful, rejoicing and not complaining, (3) Humble, simplicity, honest, forgiving, and indulgent, (4) Think positively, having good prejudice and avoid gossiping, (5) Doing good and respecting, (6) Empathizing, providing solutions, not criticizing, (7) Obeying leaders and rules. This is similar to what Byars \& Rue (2008) stated that to achieve effective organizational goals depends on the mental attitude of employees in carrying out and coping with their work because each individual has different characteristics.

Based on observations and interviews conducted with several employees, they have worked in this foundation for 5, 10, and even 35 years, starting from being an apprentice student. The employees' unique characteristics are they have a willingness to give their spare time to do work that is not part of their main task. When their work is done, they usually ask their colleagues to help their colleagues' works. They don't mind doing overtime to help finish their colleagues' works and never complain when they have lots of work. These behaviors showed the dimensions of organizational citizenship behavior, namely altruism, courtesy, and sportsmanship (Organ et al., 2006).

Copyright (C) 2021. Owned by Author(s), published by Society. This is an open-access article under the CC-BY-NC-SA license. 


\section{The Influence of Prophetic Leadership and Job Satisfaction toward Organizational Citizenship Behavior (OCB) on Employees of Prof. Dr H. Kadirun Yahya Foundation in Medan}

According to Organ et al. (2006), organizational citizenship behavior (OCB) is the behavior of free individuals, not directly recognized by the organizational reward system or formal reward system. Knowing the importance of OCB for the progress of the company, then OCB needs to be improved. Companies will not compete, change existing resources, and serve stakeholders if their employees only carry out their job descriptions. Employees must also carry out organizational citizenship behavior (OCB), namely various types of cooperation, and help other employees, supporting other employees in a social and psychological context (Wirawan, 2017).

Organizational Citizenship Behavior (OCB) can arise from various organizational factors, including job satisfaction, organizational commitment, and employee performance (Pio \& Tampi, 2018). When some employees experience problems in their work, the leader, the Chairman of the Foundation, always helps them solve these obstacles by providing feedback that causes employees to feel excited again because they feel supported. Not only that, employees of Prof. Dr. H. Kadirun Yahya Foundation always get all information related to their work from friends and leaders, so they never miss information. According to Angelina \& Subudi (2014), employees will feel happy with their leaders if they keep the promises they have agreed on together so that this makes employees not feel afraid to do extra work and help in completing other jobs outside their responsibilities because the leader must have the attitude responsible for every decision he has taken. Furthermore, Gibson et al. (2003) stated that organizations/leaders who provide good service to their employees would create confidence and job satisfaction among employees at work, causing employees to provide a service attitude and feel no objection in doing jobs that are not their main task.

According to Ramayah \& Hui, as cited in Wirawan (2017), the relationship between leaders and organizational members plays a significant role in motivating employees to conduct OCB. The relationship between the leader and its members is a voluntary acceptance of risk, which is based on the hope that a trusted person, namely the leader, can take positive actions for those who give trust, namely members, this is believed to increase OCB behavior in employees (Ezerman \& Sintaasih, 2018). Trust in leaders can improve OCB behavior for employees (Perdana \& Surya, 2017).

According to Rivai \& Arifin (2010), one example of effective leadership is leadership exemplified by the prophet Muhammad PBUH, also called prophetic leadership. Anwar (2017) mentioned that prophetic leadership is a person's ability to influence others to achieve goals done by the prophet. According to Nashori (2009), the prophet has 4 (four) traits, namely siddiq (honest), tabligh (convey/openness), amanah (responsible/able trusted), fathanah (intelligent) in planning, vision, mission, strategy, and implementing it. Meanwhile, Anwar (2017) stated that the nature of siddiq means being honest, true by being implemented in upholding the values of truth and honesty that act consistently between actions with values and principles based on laws and regulations. The second characteristic is tabligh, which means conveying the truth and never hiding what must be conveyed. Not afraid to eradicate wickedness and openness can also be interpreted as willing to accept feedback, criticism, or protests that do have a basis for anyone. The third characteristic is amanah, and a leader must take full responsibility for his subordinates and protect his subordinates' rights, such as employment rights matters. The fourth characteristic is fathanah, which means having high emotional and spiritual intelligence and professionalism in finding solutions to problems or conflicts in the organization.

While working at Prof. Dr. H. Kadirun Yahya Foundation, employees feel very happy and satisfied because the foundation has provided monthly salaries, bonuses, holiday benefits, and health insurance according to the initial agreement. Furthermore, they said that values adopted

Copyright (C 2021. Owned by Author(s), published by Society. This is an open-access article under the CC-BY-NC-SA license. https://doi.org/10.33019/society.v9i1.291

96 
in the foundation make them become better individuals. They have attended value training given every year on a rotating basis, and all employees have the same right to attend those training organized by the foundation. Employees also work in conducive and comfortable conditions to complete their work properly and on time.

According to Muafi (2018), the salary received, the relationship between employees and superiors, career, conditions in which an individual is treated fairly in his workplace can lead to job satisfaction in employees. Siagian (2018) stated that employee job satisfaction can be seen when doing work related to other aspects such as interaction with colleagues, superiors, following regulations, and the work environment.

Job satisfaction is very important for the sake of peace and the welfare of employees. When employees feel their welfare, they will work as much as possible and provide the best results to the company, and employees will also provide more effort for jobs that are not their main function. This term is known as Organizational Citizenship Behavior (OCB).

A previous study shows that if employees perceive their leaders as fair in terms of rewarding behavior, employees will tend to be more satisfied with supervisors and continue to improve themselves in the organization and show OCB behavior (Walumba, as cited in Wirawan, 2017). Other previous studies also significantly influenced leadership, job satisfaction, and organizational commitment to Organizational Citizenship Behavior (OCB) (Nurcahyo, 2012).

Based on the description above, this research was interested in finding out the influence of prophetic leadership and job satisfaction toward organizational citizenship behavior (OCB) on employees of Prof. Dr. H. Kadirun Yahya Foundation.

\section{Literature Review}

\subsection{Organizational Citizenship Behavior (OCB)}

Organizational Citizenship Behavior (OCB) is an extra-role behavior where employees can display this behavior, and OCB is a specific behavior that individuals own in the organization (Sule \& Priansa, 2018). Organizational Citizenship Behavior (OCB) is voluntary behavior in the workplace carried out by employees freely outside the requirements of one's job and organizational provisions. It does not exist in the organizational reward system implemented by employees (Wirawan, 2017). Furthermore, Ahdiyana (2010) said that someone who has high Organizational Citizenship Behavior (OCB) would not be paid in the form of money or specific bonuses. Still, Organizational Citizenship Behavior (OCB) is more about the social behavior of each individual to work beyond what is expected, such as volunteering to help colleagues work. In other words, OCB is an employee's behavior not because of the demands of his job but rather based on volunteerism, which is not formally recognized by the reward system (Organ et al., 2006).

There are five dimensions of organizational citizenship behavior (OCB), according to Organ et al. (2006), which consists of:

1) Helping others to work voluntarily (Altruism)

Altruism is helping other employees without coercion or being related to operational tasks imposed by the organization. Altruistic behavior is helping behavior that arises not because of pressure or obligation but voluntarily and not based on certain norms. This behavior, for example, helps colleagues so that the work system becomes more productive because a worker can use his spare time to help other employees with a more urgent task. 
2) Participating in various organizational activities (Civic Virtue)

Civic virtue is behavior that shows voluntary participation and support for organizational functions, both professional and social. Individuals with civic virtue behavior always play an active role in organizational activities. Playing a civic virtue includes offering suggestions about cost reduction or other resource savings, directly affecting the organizational efficiency level.

3) Behavior exceeds minimum standards (Conscientiousness)

Conscientiousness is behavior that contains the performance of role prerequisites that exceeds the minimum standard. Conscientiousness refers to the behavior of a punctual person, has high attendance levels and is above the standard requirements set by the organization. The Big Five theory explains that individuals who score high on conscientiousness traits have good self-control, are organized, prioritize tasks, follow norms and regulations. This behavior can identify that employees have accepted and obeyed the rules and procedures that exist within the organization.

4) Polite behavior (Courtesy)

Courtesy is a good deed to others but related to problems that arise in carrying out work. Referring to the word's meaning, courtesy means politeness, helping colleagues prevent problems related to their work by providing consultation and information and respecting their needs.

5) Sportsmanship

Sportsmanship is avoiding negative behavior when experiencing irritation or anger. The sportsmanship dimension can be seen from the tolerance aspect of individual complaints in their work. Individuals with high sportsmanship behavior will pay close attention to details in their work, reasonably carry out their work and complain a little, and have high adaptability to the situation and work environment. Sportsmanship is often understood as the ability to adapt to various changes or problems, even if one does not like or agree with changes in the organization. Reducing employees' complaints about sportsmanship behavior can save time and energy from HR managers in managing employees.

\subsection{Prophetic Leadership}

According to Kuntowijoyo (1991), the concept of prophetic leadership carries a humanization mission in which to humanize humans. Because basically, this humanization will raise human life's dignity and make humans responsible for what they have done. Prophetic leadership is a person's ability to influence others to achieve goals as the prophets did (AdzDzakiey, 2005). Meanwhile, according to Budiharto \& Himam (2016), prophetic leadership can control oneself and influence others sincerely to achieve common goals as practiced by the prophets.

According to Zainuddin \& Mustaqim (2012), prophetic leadership prioritizes exemplary and deliberation, a democratic leadership style, and inclusive (open) leadership style where the leader receives criticism from subordinates. Meanwhile, according to Antonio (2008), as cited in Nashori (2009), prophetic leadership is a holistic leader or a leader who can develop leadership in various fields, including self-development, business and entrepreneurship, household life, and community. This leadership style has been proven since more than 15 centuries ago, and it is still relevant to apply.

Based on the study of Budiharto \& Himam (2006), the aspects of prophetic leadership consist of 4 (four), namely as follows: 


\section{1) Siddiq}

Siddiq means true, straight, honest, patient, and consistent. The opposite of siddiq is kadzib or lie. A leader with a siddiq character is always honest with God, himself/herself, others, and the universe. Leaders also always follow the truth based on their conscience, patient, consistent, and could be an example for others. A leader with a siddiq character does not like to lie, is not easily influenced by his passions, and does not prioritize personal interests over the organization.

\section{2) Amanah}

Amanah means trustworthy, loyal, professional, and full of responsibility. The opposite of amanah is betrayal, and a trustworthy leader is always loyal to God, himself/herself, and others. Leaders work earnestly with a commitment to God, colleagues, staff, and even consumers and are fair because they realize that all tasks will also be accountable to God and the organization.

3) Tabligh

Tabligh comes from the word balagha, which means conveying information as it is. Tabligh in leadership also means transparent, open management, as well as amar ma'aruf nahi mungkar. The opposite of tabligh is hiding information and truth, including the courage to state the truth and admit mistakes. The prophetic leader expresses true openness to his God, himself/herself, and others.

4) Fathanah

Fathanah means smart and able to solve problems (a problem solver). This intelligence is built from devotion to God. The behavior of fathanah leaders is expressed in leaders' work ethic and performance who can solve problems appropriately. The opposite of fathanah is sufaha which comes from the word safihun, which means being unable to understand the essence of truth, unable to distinguish good and bad things. Leaders who are fathanah have the intelligence to optimally function their hearts, minds, and five senses to solve problems.

\subsection{Job Satisfaction}

Siagian (2018) stated that job satisfaction is an employee's general attitude towards their job; someone who is satisfied with his/her job will have a positive attitude towards the organization. Conversely, people who are dissatisfied with their work regardless of the factors that cause the dissatisfaction, such as low wages, boring jobs, unsatisfactory working conditions, will tend to have a negative attitude towards the organization where they work. According to Rivai \& Sagala (2009), job satisfaction is an evaluation that describes a person feeling happy or dissatisfied at work.

According to Luthans (2011), there are 6 (six) aspects of job satisfaction in employees, namely as follows:

1) Payment

The amount of salary received is following the workload and is balanced with other employees in the organization.

2) The job itself

If the job provides an individual opportunity to learn according to their interests and opportunities to be responsible.

3) Promotion

The opportunity to increase employees' position in the organizational structure and good performance allows the opportunity to develop oneself through upgrading, education, and training. 
4) Supervision

It depends on the superior's ability to provide technical assistance in motivating and paying every employee.

5) Teamwork

How good co-workers provide technical assistance and social encouragement and a source of support, comfort, and advice.

6) Working conditions

Namely, how comfortable and calm employees feel about their work environment, ex: work desks, air temperature, noise, etc., supporting employee performance.

\section{Research Methodology}

The main objective of this study was to examine the influence of prophetic leadership and job satisfaction toward organizational citizenship behavior (OCB) on employees of Prof. Dr. H. Kadirun Yahya Foundation in Medan. Subjects were 64 employees in Prof. Dr. H. Kadirun Yahya Foundation. OCB was measured using the OCB scale from Organ et al., (2006), prophetic leadership was measured using the prophetic leadership scale from Budiharto \& Himam (2006), job satisfaction was measured using job satisfaction scale by Luthans (2011), which have modified. The validity of the measuring instrument used is the validity of the construct through factor analysis.

The OCB scale consists of 22 items, the prophetic leadership scale consists of 18 items, and the job satisfaction scale consists of 30 items. These scales used a Likert scale model consisting of favorable and unfavorable statements with five answers: strongly disagree, disagree, neutral, agree, strongly agree. The scores range from 1 to 5 . The data were analyzed by multiple regression, and the analytical tool used is SPSS Statistics 20.0 software.

\section{Results and Discussion}

Results and discussion objectively present key results, without interpretation, and in an orderly and logical sequence using illustrative materials (tables and figures) and text. The result and discussion should be organized around a series of tables and/or figures sequenced to present key findings in a logical order. This section should include three parts: findings generated from the data and gathered information, the analysis based on research methodology, and interpretation and synthesis of findings. Include supporting data such as a table, graph, figure, and other tools that need to be presented with a clear and concise argument.

\subsection{Results}

This study's regression model will determine the influence of prophetic leadership and job satisfaction toward OCB on employees of Prof. Dr. H. Kadirun Yahya Foundation. But before testing the regression model, it is necessary to test the classic assumptions for the regression model used.

\subsubsection{Normality Test}

The normality test aimed to see whether the data is normally distributed within the normality distribution curve. 
The Influence of Prophetic Leadership and Job Satisfaction toward Organizational Citizenship Behavior (OCB) on Employees of Prof. Dr H. Kadirun Yahya Foundation in Medan

Table 1. Normality Test

\begin{tabular}{|lccc|}
\hline Variables & Z & Sig & Interpretation \\
\hline OCB & 0.102 & 0.097 & Normal \\
\hline Prophetic Leadership & 0.092 & 0.200 & Normal \\
\hline Job Satisfaction & 0.105 & 0.090 & Normal \\
\hline
\end{tabular}

Table 1 showed that the value of $Z=0.102$ ( $\mathrm{sig}>0.05)$ for the variable Organizational Citizenship Behavior (OCB), $Z=0.092$ (sig> 0.05) for prophetic leadership and $Z=0.105$ (sig> 0.05) for job satisfaction. Therefore, it can be concluded that the data for variable Organizational Citizenship Behavior (OCB), prophetic leadership, and job satisfaction are normally distributed.

\subsubsection{Linearity Test}

The linearity test was conducted to determine whether the three variables, namely the variable job satisfaction, prophetic leadership, and organizational citizenship behavior, correlate with meeting the linear line assumptions.

Table 2. Linearity Test

\begin{tabular}{|lcc|}
\hline Variables & Sig & Interpretation \\
\hline $\begin{array}{l}\text { Organizational Citizenship } \\
\text { Behavior (OCB) *prophetic } \\
\text { leadership }\end{array}$ & 0.040 & Linear \\
\hline $\begin{array}{l}\text { Organizational Citizenship } \\
\text { Behavior (OCB) *job } \\
\text { satisfaction }\end{array}$ & 0.033 & Linear \\
\hline
\end{tabular}

Table 2 showed that the correlation between prophetic leadership and Organizational Citizenship Behavior (OCB) and the correlation between job satisfaction and Organizational Citizenship Behavior (OCB) fulfill the linear line assumptions (sig <0.05).

\subsubsection{Autocorrelation Test}

The autocorrelation test aimed to see whether there is a correlation between confounding error in period $t$ and confounding error in period $t-1$ (previous). The autocorrelation test is seen from the Durbin Watson statistic. The results of data processing are shown in the table as follows:

\section{Table 3. Autocorrelation Test}

\begin{tabular}{|lcccc|}
$\mathbf{R}$ & $\mathrm{R}$ Square & Adjusted R Square & SE of the Estimate & Interpretation \\
\hline $.367^{\mathrm{a}}$ & .134 & .1068 & .548372 & 2.039 \\
\hline
\end{tabular}

From the results of statistical testing, it was found that the value of the Durbin Watson test was 2.039 (with a value of $\mathrm{dL}=1.664$ and $\mathrm{dU}=1.7361$ ), which means that the value is between $1.664-2.2639$, which means that there is no autocorrelation between the prophetic leadership and job satisfaction variables. 


\subsubsection{Multicollinearity Test}

According to Ghozali (2005), the multicollinearity test aims to determine whether the regression model found a correlation between independent variables. A good regression model should not correlate with the independent variables. To detect multicollinearity, we use Variance Inflation Factor (VIF) value. If VIF $<5$, then the model does not have multicollinearity. The multicollinearity test results can be seen in the following table:

\section{Table 4. Multicollinearity Test}

\begin{tabular}{|ccc|}
\hline Variables & Tolerance & VIF \\
\hline Prophetic Leadership & 0.999 & 1.001 \\
\hline Job Satisfaction & 0.999 & 1.001 \\
\hline
\end{tabular}

Table 4 showed that multicollinearity does not occur because the VIF value is $<5$. There is no correlation between prophetic leadership and job satisfaction variables or multicollinearity in the regression model.

\subsubsection{Heteroscedasticity Test}

The heteroscedasticity test aims to observe whether there is a variance inequality from the residuals of one observation to another. If the residual variance from one observation to another is constant, it is called homoscedasticity, and if it is different, it is called heteroscedasticity. The heteroscedasticity test can be done by looking at the graph plot as follows:

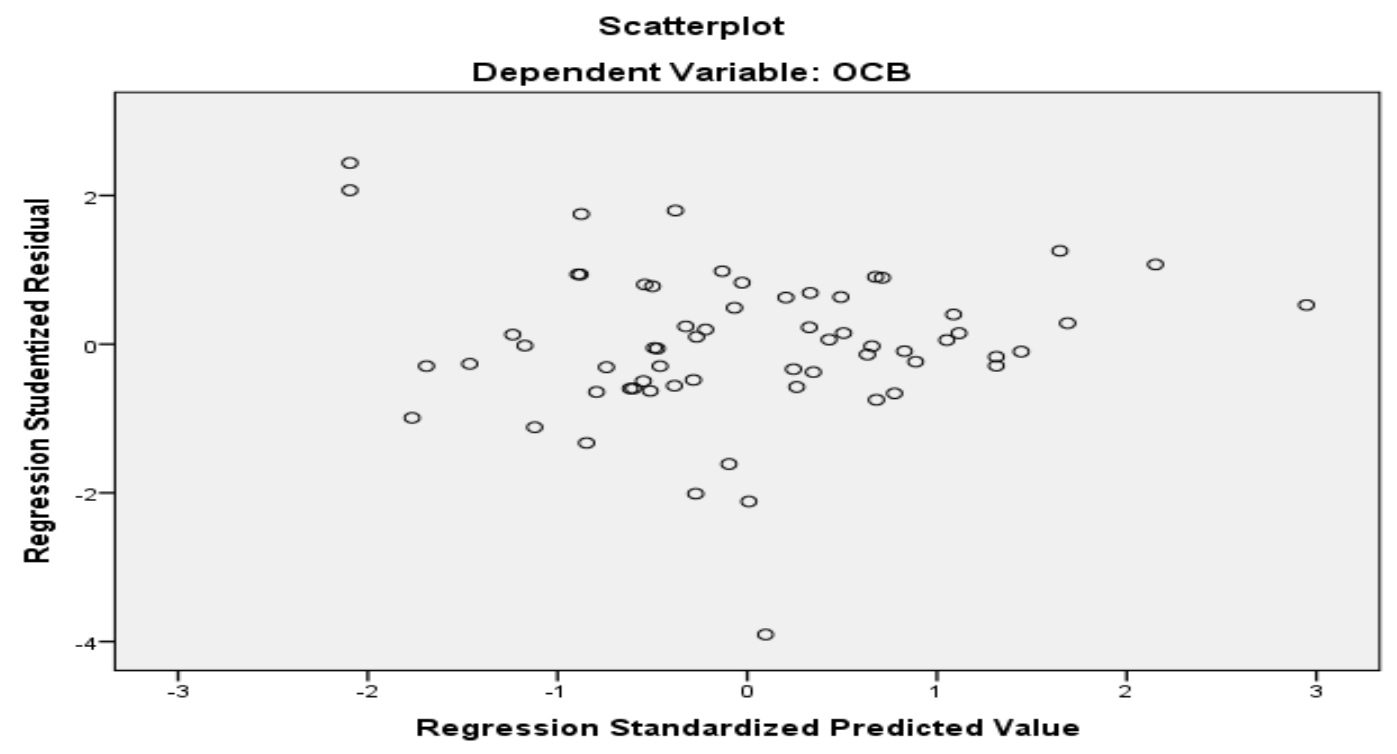

Figure 1. Scatterplot

Figure 1 showed that the dots spread randomly and do not form a clear pattern and spread both above and below the number 0 on the Y-axis. This means that there is no heteroscedasticity or variance from one observation's residuals to another. 
The Influence of Prophetic Leadership and Job Satisfaction toward Organizational Citizenship Behavior (OCB) on Employees of Prof. Dr H. Kadirun Yahya Foundation in Medan

\subsubsection{Simultaneous Test (F Test)}

Table 5. Simultaneous Test (F Test) Analysis of Variance

\begin{tabular}{|lrcccc|}
\hline \multicolumn{1}{|c}{ Model } & Sum of Squares & df & Mean Square & F & Sig. \\
\hline Regression & 692.683 & 2 & 346.342 & 4.740 & $.012^{\mathrm{b}}$ \\
\hline Residual & 4457.551 & 61 & 73.075 & & \\
\hline Total & 5150.234 & 63 & & & \\
\hline
\end{tabular}

a. Dependent Variable: $\mathrm{OCB}$

b. Predictors: (Constant), Prophetic Leadership, Job Satisfaction

From Table 5, it can be seen that the calculated F value (4.740) is greater than the F table (3.07), and the sig value $=0.012(<0.05)$. This means that prophetic leadership and job satisfaction simultaneously significantly influence Organizational Citizenship Behavior (OCB) on employees of Prof. Dr. H. Kadirun Yahya Foundation.

\subsubsection{Coefficient of Determination (R2)}

Table 6. Coefficient of Determination (R2) Model Summary ${ }^{b}$

\begin{tabular}{|ccccc|} 
Model & $\mathbf{R}$ & R Square & Adjusted R Square & $\begin{array}{c}\text { Std. Error of the } \\
\text { Estimate }\end{array}$ \\
\hline $.367 \mathrm{a}$ & .134 & .106 & 8.54837 & \\
\hline
\end{tabular}

a. Predictors: (Constant), Prophetic Leadership, Job Satisfaction

b. Dependent Variable: OCB

From Table 6, it is known that the coefficient of determination (R Square) obtained is 0.134. OCB is influenced by prophetic leadership and job satisfaction by $13.4 \%$, while the remaining $86.6 \%$ is influenced by other factors that are not examined.

\subsubsection{Partial T-Test}

Table 7. Statistical Result of T-Test Coefficients

\begin{tabular}{|c|c|c|c|c|c|}
\hline \multirow{2}{*}{ Model } & Unstandardized Coefficients & Standardized & \multicolumn{2}{c|}{ T } \\
& Coefficients & & \\
(Constant) & 71.586 & 16.370 & & 4.373 & 0.000 \\
\cline { 2 - 5 } X1 & 0.262 & 0.118 & 0.264 & 2.215 & 0.031 \\
X2 & 0.285 & 0.130 & 0.261 & 2.190 & 0.032 \\
\hline
\end{tabular}

Table 7 showed that the variable prophetic leadership and job satisfaction positively influence OCB, which means that when prophetic leadership is demonstrated by the Chairman of the foundation and job satisfaction increases, so does the OCB of the employees. Furthermore, from the table above, the significance value of the prophetic leadership variable 
(X1) is 0.031 (sig $<0.05)$, or with a value $t$ count $(2,215)$ is greater than $t$ table $(1,980)$. There is a significant influence of prophetic leadership toward Organizational Citizenship Behavior (OCB) of employees on Prof. Dr. H. Kadirun Yahya Foundation. The significance value of the job satisfaction variable $(\mathrm{X} 2)$ is 0.032 ( $\mathrm{sig}<0.05)$, or with the $\mathrm{t}$ value $(2.190)$ greater than the $\mathrm{t}$ table (1.980). There is a significant influence of job satisfaction toward organizational citizenship behavior (OCB) on employees of Prof. Dr. H. Kadirun Yahya Foundation.

\subsection{Discussion}

This study follows Arifin \& Himam (2019) that prophetic leadership is one factor shaping Organizational Citizenship Behavior (OCB) in employees. Employees will give a positive response and produce better performance when they have voluntary behavior towards their leader. Leaders who carry out leadership according to the prophet's leadership tend to increase employee volunteerism at work. This extra-role behavior in Islam is known as good deeds with sincerity. Employees behave in different roles (OCB) because they want to get blessing from God. This will drive success for an organization. Trust and support from leaders in helping their subordinates will cause subordinates to take the initiative and respond with behavior to help them achieve their goals (van Emmerik et al., 2008). Furthermore, the result is also in line with Siagian (2018) that someone satisfied with his/her job will positively affect the organization where he/she works. One of the positive attitudes is shown through the extra behavior of employees by helping their co-workers work voluntarily without expecting anything in return from the organization.

\section{Conclusion}

Based on the obtained results, it can be concluded that prophetic leadership and job satisfaction have a significant positive influence on organizational citizenship behavior (OCB) on employees of Prof. Dr. H. Kadirun Yahya Foundation. The influence of prophetic leadership and job satisfaction toward OCB on employees of Prof. Dr. H. Kadirun Yahya Foundation was $13.4 \%$. This means that prophetic leadership and job satisfaction contributed effectively as much as $13.4 \%$ in generating OCB. At the same time, the rest is influenced by other factors that were not examined in this study.

\section{Acknowledgement}

The authors would like to thank the authorities at Universitas Sumatera Utara, which have funded this research based on the contract for implementing the TALENTA research for the 2020 funding year, with contract number 369/UN5.2.3.1/PPM/SPP-TALENTA USU/2020, April 28, 2020.

\section{Declaration of Conflicting Interests}

The authors have declared no potential conflicts of interest concerning the study, authorship, and/or publication of this article.

\section{References}

Adz-Dzakiey, H. B. (2005). Menumbuhkan dan Mengembangkan Potensi Kepemimpinan melalui Prophetic Intelligence Management. Hand Out Mata Kuliah Studi Kepemimpinan Islam. Yogyakarta: Universitas Cokroaminoto.

Copyright (C) 2021. Owned by Author(s), published by Society. This is an open-access article under the CC-BY-NC-SA license. 
Ahdiyana, M. (2010). The dimention of Organizationalcitizenship behavior within organization performance. Journal of Applied Psychology, 8(2), 1-10.

Angelina, A., \& Subudi, M. (2014). Pengaruh kompensasi Finansial dan Gaya Kepemimpinan terhadap Kepuasan Kerja Karyawan dan Organizational Citizenship Behavior (OCB) pada Hotel Alit's Beach Bali. E-Jurnal Manajemen, 3(4), 1035-1049. Retrieved from https://ojs.unud.ac.id/index.php/Manajemen/article/view/7559

Anwar, A. (2017). Tipe kepemimpinan profetik konsep dan implementasinya dalam kepemimpinan di perpustakaan. Pustakaloka, 9(1), 69-82. Retrieved from http://jurnal.iainponorogo.ac.id/index.php/pustakaloka/article/view/920

Arifin, Z., \& Himam, F. (2019). Peran Kepemimpinan Profetik Atasan dan Etika Kerja Islami Terhadap Organizational Citizenship Behavior Pada Anggota Lembaga Dakwah Islam di UGM (Thesis). Yogyakarta, Indonesia: Fakultas Psikologi, Universitas Gajah Mada.

Budiharto, S., \& Himam, F. (2006). Konstruk Teoritis dan Pengukuran Kepemimpinan Profetik. Jurnal Psikologi, 33(2), 133-146. Retrieved from https://journal.ugm.ac.id/jpsi/article/view/7081

Byars, L. L., \& Rue, L. W. (2008). Human Resource Management. New York, United States: McGraw-Hill Education.

Ezerman, M. M., \& Sintaasih, D. K. (2018). Effect of Servant Leadership, Trust in Leadership on Organizational Citizenship Behavior with Interpersonal Communications as Mediations Variables. IOSR Journal of Business and Management, 20(4), 21-30. Retrieved from http://www.iosrjournals.org/iosr-jbm/papers/Vol20-issue4/Version-

5/D2004052130.pdf

Gibson, J. L., Ivancevich, J. M., Donnelly, J. H., \& Konopaske. R. (2003). Organization: Behavior, Structure, and Processes (11th ed.). New York, United States: McGraw-Hill.

Ghozali, I. (2005). Aplikasi Analisis Multivariate SPSS. Semarang, Indonesia: Universitas Diponegoro.

Kuntowijoyo. (1991) . Paradigma Islam; Interpretasi untuk Aksi. Bandung, Indonesia: Mizan.

Lim, Y. H., Kee, D. M. H., Lai, X. Y., Lee, Z. M., Low, M. Q., Sariya, S., \& Sharma, S. (2020). Organizational Culture and Customer Loyalty: A Case of Harvey Norman. Asia Pacific Journal of Management and Education, 3(1), 47-62. https:// doi.org/10.32535/apjme.v3i1.743

Luthans, F. (2011). Organizational Behavior: an Evidence-Based Approach. New York, United States: McGraw Hill/Irwin.

Muafi. (2008). Perilaku Organisasi. Yogyakarta, Indonesia: Wimaya Press.

Nashori, F. (2009). Psikologi Kepemimpinan. Yogyakarta, Indonesia: Pustaka Fahima.

Nurcahyo, R. J. (2012). Pengaruh Kepemimpinan, Kepuasan Kerja dan Komitmen Organisasional terhadap Organizational Citizenship Behavior (OCB) Perawat RSD Panembahan Senopati Bantul. Sinergi: Kajian Bisnis dan Manajemen, 13(1), 41-55. Retrieved from https://journal.uii.ac.id/Sinergi/article/view/3828

Organ, D. W., Podsakoff, P. M., \& MacKenzie, S. B. (2006). Organizational citizenship behavior: Its nature, antecedents, and consequences. SAGE Publications, Inc., https://www.doi.org/10.4135/9781452231082

Perdana, I., \& Surya, I. (2017). Pengaruh Servant Leadership dan Trust In Leadership terhadap Organizational Citizenship Behaviour. E-Jurnal Manajemen, 6(6), 3225 - 3251. Retrieved from https:/ / ojs.unud.ac.id/index.php/Manajemen/article/view/29948 
Pio, R. J., \& Tampi, J. R. E. (2018). The influence of spiritual leadership on quality of work life, job satisfaction and organizational citizenship behavior. International Journal of Law and Management, 60(2), 757-767. https:/ / doi.org/10.1108/ijlma-03-2017-0028

Rivai, V., \& Sagala. E. J. (2009). Manajemen Sumber Daya Manusia untuk Perusahaan. dari Teori dan Praktik. Jakarta, Indonesia: PT Raja Grafindo Persada.

Rivai, V., \& Arifin. A, (2010). Islamic Banking. Jakarta, Indonesia: PT Bumi Aksara.

Siagian, S. P. (2018). Manajemen Sumber Daya Manusia. Jakarta, Indonesia: PT Bumi Aksara.

Sule, E. T., \& Priansa, J. D. (2018). Kepemimpinan dan Perilaku Organisasi : Membangun Organisasi Unggul di Era Perubahan. Bandung, Indonesia: PT Refika Aditama.

van Emmerik, I. H., Euwema, M. C., \& Wendt, H. (2008). Leadership Behaviors around the World. International Journal of Cross Cultural Management, 8(3), 297-315. https:// doi.org/10.1177/1470595808096671

Wirawan (2017). Kepemimpinan : Teori, Psikologi, Perilaku Organisasi, Aplikasi dan Penelitian. Jakarta, Indonesia: Rajawali Pers.

Zainuddin. M., \& Mustaqim. (2012). Studi Kepemimpinan Islam (konsep, teori, dan prakteknya dalam sejarah). Yogyakarta, Indonesia Suka-Press UIN Sunan Kalijaga.

\section{About the Authors}

1. Sherry Hadiyani obtained her Master's degree in Psychology from Universitas Sumatera Utara, Indonesia, in 2013. The author is an Assistant Professor at the Department of Psychology, Faculty of Psychology, Universitas Sumatera Utara, Indonesia.

E-Mail: sherryhadiyani@usu.ac.id

2. Abdhy Aulia Adnans obtained his Doctoral degree in Management Science from Universitas Padjadjaran, Indonesia, in 2017. The author is an Assistant Professor at the Department of Psychology, Faculty of Psychology, Universitas Sumatera Utara, Indonesia. E-Mail: abdhy_aulia@yahoo.com

3. Ferry Novliadi obtained his Master's degree in Psychology from Universitas Gadjah Mada, Indonesia, in 2005. The author is an Assistant Professor at the Department of Psychology, Faculty of Psychology, Universitas Sumatera Utara, Indonesia.

E-Mail: novliadi@yahoo.com

4. Fahmi obtained his Master's degree in Psychology from Universitas Sumatera Utara, Indonesia, in 2012. The author is an Assistant Professor at the Department of Psychology, Faculty of Psychology, Universitas Sumatera Utara, Indonesia.

E-Mail: fahmi.psi@gmail.com 